J. Clin. Chem. Clin. Biochem.

Vol. 19,1981 , pp. $357-361$

\title{
Factor XII Assay with the Chromogenic Substrate Chromozym PK ${ }^{\circledR 1}$ )
}

\author{
By W. Dick, W. Cullmann
}

Dept. of Clinical Chemistry of the Lukas Hospital Neuß, F.R. G.,

\author{
N. Müller
}

Institute of Experimental Haematology and Blood Transfusion of the University of Bonn, F.R.G. and

K. Adler

Dept. of Int. Med. of the University of Cologne, F.R.G.

(Received October 4, 1980/January 26, 1981)

Summary: A chromogenic assay for the determination of factor XII using the chromogenic substrate Chromozym $\mathrm{PK}^{\circledast}$ was evaluated. The assay was linear in the range $10 \mathrm{U} / 1$ to more than $200 \mathrm{U} / 1$. Using the assay, the normal range of factor XII ( 50 healthy volunteers at random) was $136 \mathrm{U} / 1 \pm 27 \mathrm{U} / 1$. Kallikrein-inhibiting concentrations of aprotinin did not influence factor XII. Comparison of the chromogenic with the clotting assay resulted in a correlation coefficient of $r=0.831$ ( $p$-value $<0.001$ ). In patients with deep vein thrombosis, factor XII level was found to be reduced to about $60 \%$ of normal activity.

\section{Ein photometrisches Verfahren zur Faktor XII-Bestimmung mit dem chromogenen Substrat Chromozym ${ }^{\circ}{ }^{\circledR}$}

Zusammenfassung: Es wird über ein photometrisches Verfahren zur Faktor XII-Bestimmung mit dem chromogenen Substrat Chromozym PK ${ }^{\circledR}$ berichtet. Linearität ist bis zu mehr als $200 \mathrm{U} / 1$ gewährleistet. Bei 50 gesunden Probanden wurde der Normalbereich zu $136 \mathrm{U} / 1 \pm 27 \mathrm{U} / \mathrm{l}$ ermittelt. Ein Zusatz von Aprotinin, der zu einer vollständigen Hemmung von Kallikrein führt, verursachte keine Hemmung der Faktor XII-Aktivität. Der methodische Vergleich mit dem Einphasentest nach Ratnoff \& Colopy ((1955) J. Clin. Invest. 34, 602-614) ergab einen Korrelationskoeffizienten von $\mathrm{r}=0.831(\mathrm{p}<0.001)$. Patienten mit einer tiefen Venenthrombose wiesen eine um $40 \%$ erniedrigte Faktor XIIAktivität auf. .

\section{Introduction}

Factor XII can be measured by exploiting its ability to generate kallikrein from prekallikrein. Cochrane et al. used benzoyl- $L$-arginine ethyl ester in an highly purified system to determine the generated kallikrein (1). With the development of a chromogenic substrate for plasma kallikrein (Chromozym $\ddot{P K}^{\circledR}$, benzoyl-prolyl-phenylalanyl-arginine- $p$-nitroanilide), this assay can be modified for measurement in plasma. Kluft has demonstrated that factor XII itself does not split the chromogenic substrate (2). On the other hand, it is necessary to rule out the unspecific splitting of the substrate by plasmin and trypsin. Cochrane et al. did not observe any influence of $2.5 \mathrm{~g} / 1$ of $\epsilon$-aminocaproic acid on the activation of factor XII (1). It is well established that after activation of plasma with negatively charged particles, kallikrein becomes inactivated within minutes. $\mathrm{Cl}$ esterase inhibi- tor is known to be the major inhibitor of kallikrein (3). Consequently, factor XII determination can be carried out with the addition of a new pre-kallikrein source to the sample, after the kallikrein of the sample is inhibited. The use of the chromogenic substrate Chromozym PK ${ }^{\circledR}$ for factor XII determination and its diagnostic value in thrombotic diseases has been investigated in this study.

\section{Methods and Materials}

Samples

To obtain the normal range, the assay for factor XII was carried out on 50 healthy volunteers selected at random, who showed normal levels for partial thromboplastin time, thrombin time, fibrinogen, and antithrombin III.

1) Reported in part at the 7 th World Congress on Thrombosis and Haemostasis in London, July 1979. 
Furthermore, the assay was carried out daily during one week on 10 healthy volunteers (aged from 36 to 54 years) and on 10 patients with deep vein thrombosis ( 4 male, 6 female, aged from 32 to 69 years) receiving treatment with a therapeutic dose of heparin (600 I. U./d $\cdot \mathrm{kg}$ body weight).

Citrated blood was taken ( 1 vol. sodium citrate and 9 parts of venous blood) and immediately centrifuged at $3000 \mathrm{U} / \mathrm{min}$ for 10 minutes at $4{ }^{\circ} \mathrm{C}$. Samples were then stored at $-40^{\circ} \mathrm{C}$. Pool plasma was obtained from at least 20 healthy donors, immediately frozen and thawed at $37^{\circ} \mathrm{C}$ just before use.

\section{Procedures}

Clotting factor XII assay was performed according to Ratnoff $\&$ Colopy (4). Standard procedures were used for the antithrombin III assay with the chromogenic substrate Chromozym TH ${ }^{\circledR}$ (Boehringer Mannheim, FRG) (5), partial thromboplastin time (6), thrombin time (7), and fibrinogen (8).

\section{Materials}

Factor XII-deficient plasma (of congenital deficiency) was obtained from Merz \& Dade (Bern, Switzerland), aprotinin (Trasylol ${ }^{\circledR}$ ) from Bayer Leverkusen, Cephotest ${ }^{\circledR}$ from Nyegaard (Oslo, Norway), and the chromogenic substrates from Boehringer Mannheim (FRG). Prof. Opferkuch, Bochum, and Prof. Loos, Mainz, kindly supplied preparations of complement subcomponents: $\mathrm{Cl}$ esterase (specific activity $3800 \mathrm{U} / \mathrm{mg}$ protein with $\mathrm{N}$-acetyl- $L$-tyrosine ethyl ester as the substrate) and $C 1 q$ subcomponent (specific activity $3.5 \times 10^{15}$ effective molecules of $\mathrm{C} 1 \mathrm{q}$ subfragment per litre) $(9,10)$.

\section{Results}

\section{Methodical studies}

\section{Inactivation of kallikrein}

In figure 1 the inactivation of kallikrein is shown after activation of normal human plasma with Cephotest ${ }^{\circledR}$ using the procedure described by Stormoken et al. (20). Furthermore, it is obvious that the kallikrein activating activity remains unchanged up to 120 minutes after activation with kaolin.

\section{Activation of factor XII}

Because the activator of factor XII has to be removed, kaolin was added as an activator. $2.5 \mathrm{~g} / \mathrm{l}$ of $\epsilon$-aminocaproic acid was added to preclude an activation of the fibrinolytic system.

After incubation of plasma with $5 \mathrm{~g} / \mathrm{l}$ of kaolin in a ratio of $1: 1$ at $37^{\circ} \mathrm{C}$ for 3 minutes, kaolin was removed by

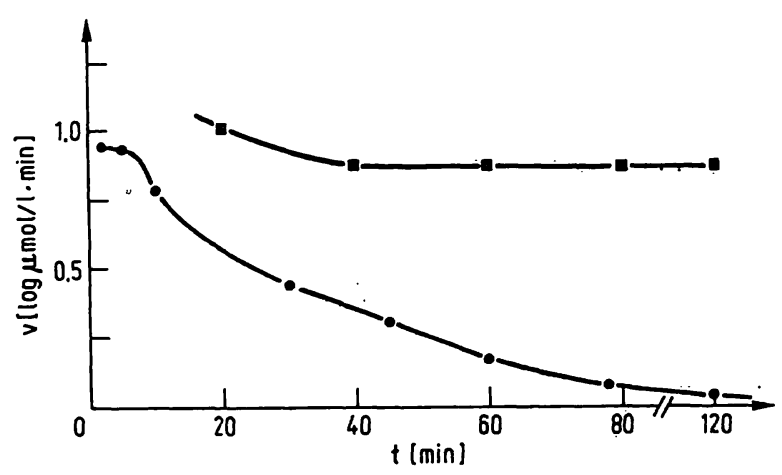

Fig. 1. Kinetics of inactivation of kallikrein $(\bullet)$ in plasma while the kallikrein generating activity ( $($ ) $)$ remains constant. centrifugation for 10 minutes at $3000 \mathrm{~g}$ at room temperature. The sample was then allowed to stand at $37^{\circ} \mathrm{C}$ for one hour to inactivate the kallikrein.

\section{Elimination of XII (fragment) activity}

It is known that the XIIf activity can be inhibited by addition of $0.3 \mathrm{~mol} / 1$ of sodium chloride $(12,13)$. The influence of increasing addition of sodium chloride in the photometric assay can be taken from figure 2. After addition of $0.3 \mathrm{~mol} / \mathrm{l}$ of sodium chloride to the assay solution, the remaining activity can be attributed to the factor XII a molecule.

\section{Photometric assay}

The buffer used consisted of Tris (final concentration $0.03 \mathrm{~mol} / \mathrm{l}$ ), sodium chloride (final concentration $0.3 \mathrm{~mol} / \mathrm{l}$ ), and aprotinin (final concentration $2.5 \mathrm{nmol} / \mathrm{l})$, adjusted to $\mathrm{pH} 8.0$ with $\mathrm{HCl}(1 \mathrm{~mol} / \mathrm{l})$. In further experiments $50 \mu \mathrm{l}$ pool plasma was found to be sufficient as a prekallikrein source in the assay.

The reaction mixture can be summarized as follows:

$300 \mu \mathrm{l}$ buffer

$50 \mu \mathrm{l}$ pool plasma (as a prekallikrein source)

$50 \mu \mathrm{l}$ activated plasma (sample)

allow to stand for 60 seconds, then start with $100 \mu 1$ Chromozym PK ${ }^{\circledR}$ (final concentration $250 \mu \mathrm{mol} / \mathrm{l}$ ). The activity can be calculated from the increasing $a b$ sorbance at $405 \mathrm{~nm}$. An assay performed on factor XIIdeficient plasma revealed no detectable activity. The principle of the assay is summarized in table 1.

Tab. 1. Principle of the chromogenic assay:

factor XII $\stackrel{\text { kaolin }\left(3 \mathrm{~min} \text { at. } 37^{\circ} \mathrm{C}\right)}{\rightleftharpoons}$ activated factor XII

kallikrein (sample) $\stackrel{\text { incubation }\left(1 \mathrm{~h} \text { at } 37^{\circ} \mathrm{C}\right)}{\rightleftharpoons}$ kallikrein (inactive)

prekallikrein (new source) $\stackrel{\text { XII a }}{\rightleftharpoons}$ kallikrein

Chromozym PK $+\mathrm{H}_{2} \mathrm{O} \stackrel{\text { kallikrein }}{\longleftarrow}$ peptide $+p$-nitroaniline

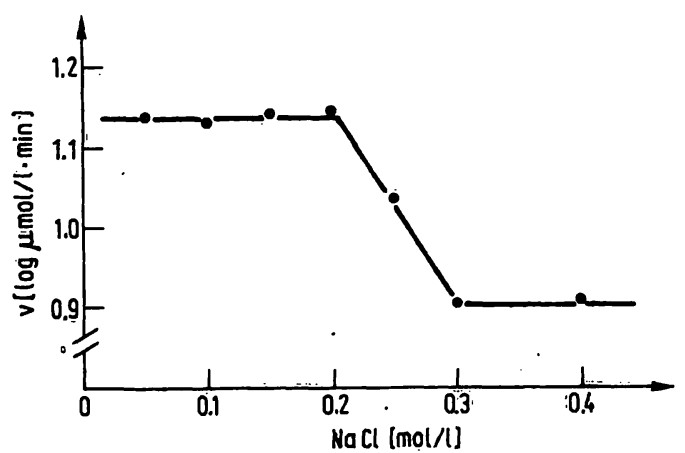

Fig. 2. Elimination of factor XIIf (fragment) activity: addition of sodium chloride to the photometric reaction mixture. (standard conditions). 


\section{Influence of storage on factor XII and prekallikrein}

Storage of normal human plasma at $4{ }^{\circ} \mathrm{C}$ resulted in the well-known initial decrease of prekallikrein. On the other hand, factor XII levels remained constant within the first 24 hours, followed by a slight decrease (fig. 3).

\section{Linearity of the assay}

A linear slope function can be obtained up to $200 \mathrm{U} / 1$ (fig. 4).

\section{Within-run precision}

For the determination of the within-run precision the chromogenic as well as the clotting assay were performed 20 times in pool plasma. For the chromogenic assay, $\bar{x}=139 \pm 4.1 \mathrm{U} / 1$ (variation coefficient $2.9 \%$ ) and for the clotting assay $\bar{x}=100 \pm 2.6 \%$ of normal activity (variation coefficient $2.6 \%$ ) were obtained.

\section{Day to day precision}

For day to day precision, $137 \pm 8.4 \mathrm{U} / 1$ (variation coefficient $6.1 \%$ ) were obtained with the amidolytic assay $(n=20)$. A pool plasma was used as described above.

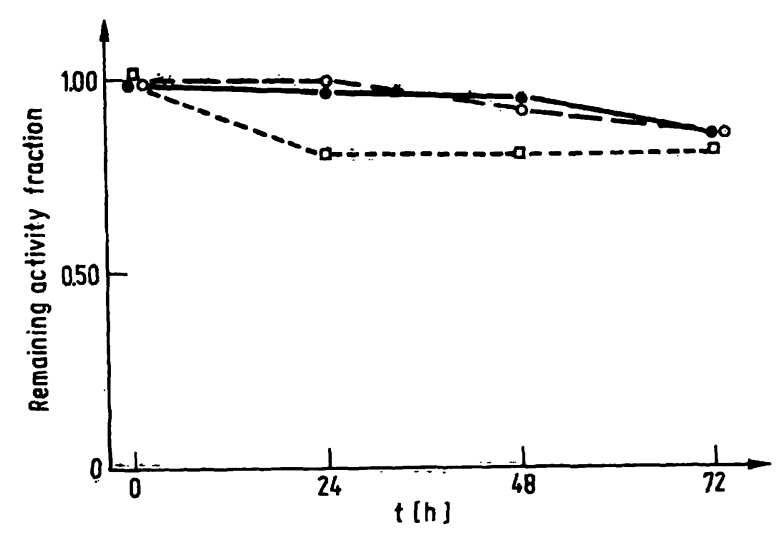

Fig. 3. Influence of storage at $4{ }^{\circ} \mathrm{C}$ on prekallikrein and factor XII; $0--0$ kallikrein, $\longrightarrow-$ factor XII (amidolytic assay), $0-\rightarrow \circ$ factor XII (clotting method).

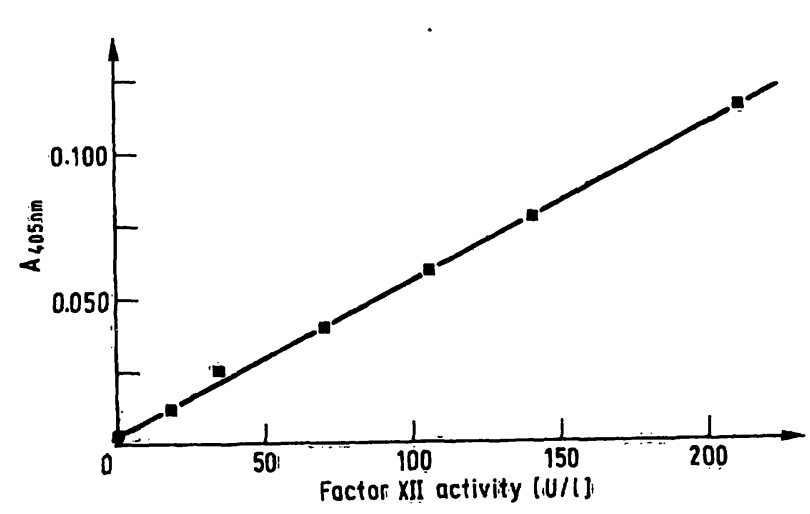

Fig. 4. Linearity of the amidolytic assay, obtained with human normal plasma (ständard conditions).

\section{Interaction of factor XII with aprotinin}

Aprotinin was added to the activation solution in concentrations ranging from $10^{-9}$ to $10^{-6} \mathrm{~mol} / \mathrm{l}$, and simultaneously to kallikrein assays. Aprotinin is effective on kallikrein at concentrations of more than $10^{-8} \mathrm{~mol} / \mathrm{l}$. Even at a concentration of $10^{-6} \mathrm{~mol} / \mathrm{l}$, this substance has a negligable effect on factor XII (fig. 5).

\section{Activation of factor XII by $\mathrm{C} 1$ esterase:}

Incubation of plasma with $\mathrm{Cl}$ esterase for 10 minutes resulted in an activation of factor XII (fig. 6). In a simultaneous assay with factor XII-deficient plasma, only a negligable activity was detected which is likely to be due to an unspecific splitting of the chromogenic substrate by $\mathrm{C} 1$ esterase. A further experiment demonstrated that the unspecific splitting of the chromogenic substrate by $\mathrm{C} 1$ esterase amounted to less than $2 \%$ of the splitting observed above. $\mathrm{Cl}$ q subcomponent in a concentration ranging from $8.7 \times 10^{12}$ to $175 \times 10^{12}$ effective molecules per litre failed to activate factor XII.

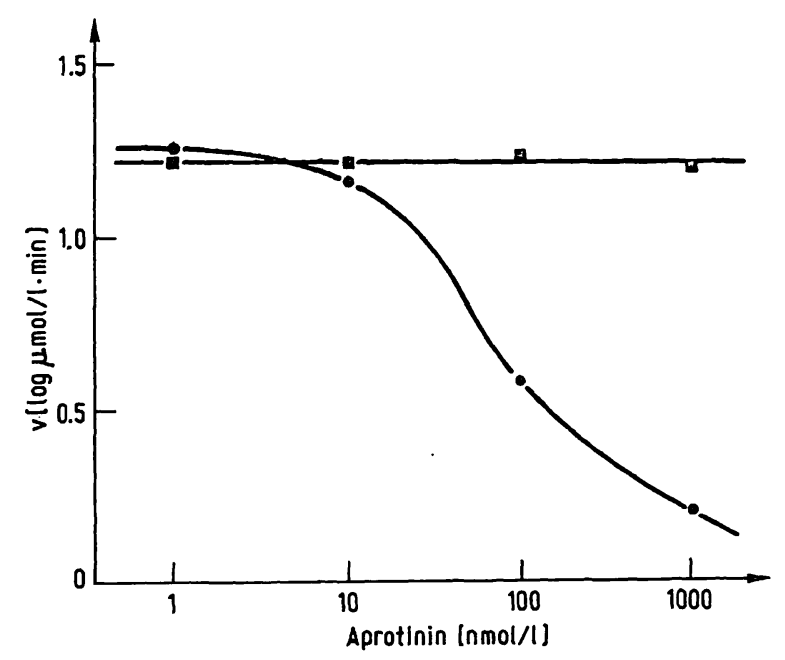

Fig. 5. Addition of aprotinin to the kallikrein $(\bullet)$ and to the amidoly tic factor XII assay (v).

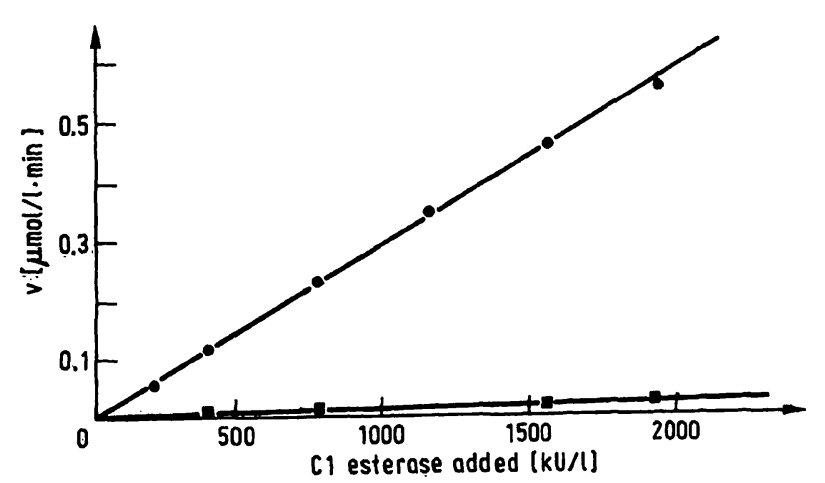

Fig. 6. Activation of factor XII by addition of purified $\mathrm{Cl}$ esterase (incubation time 10 minutes); - normal plasma, - factor XII deficient plasma. 
Diagnostic evaluation of the chromogenic assay and comparison with the clotting method

Using both methods factor XII was evaluated daily for one week on 10 volunteers and on 10 patients with deep vein thrombosis. Table 2 demonstrates that in the case of the patients with deep vein thrombosis, factor XII level was markedly lowered. Correlation of the mean values obtained during one week with the amidolytic assay on the one hand, and the clotting method on the other hand resulted in a correlation coefficient of $r=0.831$ ( $p$-value $<0.001$ ) (fig. 7). Linear regression analysis showed the equation: $\mathrm{y}=0.759 \mathrm{x}+23$.

\section{Discussion}

Exposure of plasma to various negatively charged surfaces like kaolin, ellagic acid or dextran sulphate initiates contact activation resulting in the activation of the intrinsic coagulation, the kinin-forming, and the fibrinolytic systems. Surface-binding of factor XII does not convert the inactive to the active form, but it makes factor XII much more susceptible (100 to 500 fold) to proteolytic activation by various proteases (11). These findings confirm a previous report that the uptake of factor XII onto kaolin is inhibited by plasma, resulting in an insufficient activation (1). However, in the presence of

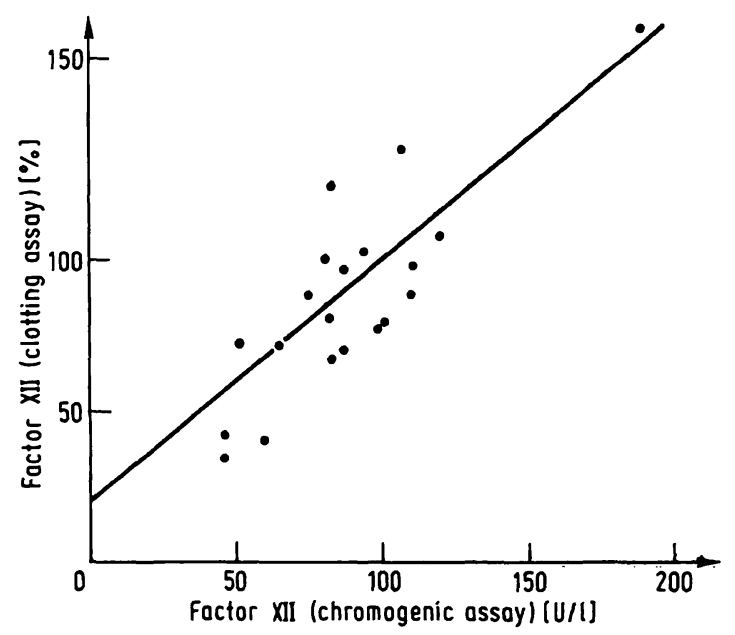

Fig. 7. Comparison of the amidolytic and the clotting assay. The mean values obtained during one week in 20 patients are compared; $y=0.759 x+23, r=0.831$ ( $p$-value $<0.001$ ).

Tab. 2. Factor XII levels of healthy donors and of patients with deep vein thrombosis (DVT) (comparison of the mean values).

\begin{tabular}{lll}
\hline & $\begin{array}{l}\text { Clotting } \\
\text { method } \\
\text { (\% of normal } \\
\text { activity) }\end{array}$ & $\begin{array}{l}\text { Chromogenic } \\
\text { assay }\end{array}$ \\
& (U/1) \\
\hline Healthy donors $(n=10)$ & $102 \pm 14.0$ & $\begin{array}{r}136 \pm 21.0 \\
\text { Patients with DVT }(n=10)\end{array}$ \\
\hline
\end{tabular}

traces of kallikrein or other proteases like plasmin or trypsin, a sufficient activation of factor XII is observed (1).

Attention must be drawn to the recent report by $\mathrm{Col}$ man (12), which attributes the coagulant activity of factor XII to the factor XII a molecule. Coagulant activity of factor XIIf (fragment) is very poor, though factor XIIf remains an activator of prekallikrein (12). Furthermore, the findings of Colman (12) indicate that factor XIIf is identical with the pre-albumin activator of prekallikrein, which was first reported by Kaplan \& Austen $(13,14)$. These authors demonstrated that the prealbumin activator is completely inhibited by $0.3 \mathrm{~mol} / 1$ sodium chloride. Consequently, factor XIIf can be excluded by adding sodium chloride to the reaction mixture. All this considered, prekallikrein activation in the assay is likely to be due to factor XII a activity.

It is known from the literature that kaolin cannot be used as an activator in highly purified systems, as factor XII is irreversibly bound to kaolin. However, in human plasma, this effect is negligible (1). In our asșay, human normal plasma was taken as a prekallikrein source; consequently the activator had to be removed from the sample. Kaolin was added as an activator. An inactivation of factor Xiİ a by antithrombin III, even in the presence of heparin, seems unlikely, as antithrombin III does not have a high affinity for contact factors in the presence of near normal concentrations of proteinase inhibitors (19). Moreover, the factor XII-dependent generation of plasma kallikrein is not inhibited by addition of heparin, indicating that the activators of prekallikrein are not counteracted by heparin (19).

Although comparison of the clotting assay with an amidolytic assay reveals many problems, an attempt was made to cortelate both methods. Comparison of the mean values obtained from the observation period resulted in an adequate correlation coefficient. Behaviour of aprotinin as ascertained in this study conforms to that ascertained in previous reports $(15,16)$.

It is known from the literature (17) that the complement system is activated by contact. However, to the best of our knowledge an activation of factor XII by $\mathrm{Cl}$ esterase has not been described. The findings of Kluft indicated that $\mathrm{C} 1$ esterase is ineffective as an activator of prekallikrein (2).

In order to gain further evidence of the interaction of factor XII and the $\mathrm{C} 1$ component of the complement system, the ability of $\mathrm{C} 1 \mathrm{q}$ to activate factor XII was explored. As our results revealed this subcomponent to be ineffective, an esterolytic activation of factor XII can be assumed. These findings could not be repeated with plasma from a case of congenital factor XII deficiency; they can therefore be attributed to an interaction of $\mathrm{C} 1$ esterase and factor XII. This pathway demonstrates the close connection of the complement and the coagulation systems. 
The diagnostic relevance of the amidolytic assay was evaluated in patients with deep vein thrombosis, as already mentioned. Using the assay, the levels of factor XII were found to be lowered during the observation period. Our results agree with the recent report of Hedner who observed IgG antibodies directed against factor XII in 11 young patients with severe thrombotic disease (18). The author concluded that normal factor

\section{References}

1. Cochrane, C. G., Revak, S. D. \& Wuepper, K. D. (1973), J. Exp. Med. 138, 1564-1583.

2. Kluft, C. (1978), J. Lab. Clin. Med. 91, 83-95.

3. Gallimore, M. J., Amundsen, E., Larsbraaten, M., Lyngaas, K. \& Fareid, E. (1979), Thromb. Haemost. 42, 261 (abstr.).

4. Ratnoff, O. D. \& Colopy, J. E. (1955), J. Clin. Invest. 34, 602-614.

5. Róka, L. (1976), Diagnosis Today (Boehringer Mannheim).

6. Rodman, N. F., Barrow, E. M. \& Graham, J. B. (1958), Amer. J. Clin. Pathol. 29, 525-535.

7. Quick, A. J. (1936), Amer. J. Physiol. 116, 535-546.

8. Clauss, A. (1957), Acta Haematol. (Basel) 17, 237-245.

9. Haines, A. L. \& Lepow, I. H. (1964), J. Immunol. 92, 456467.

10. Haines, A. L. \& Lepow, I. H. (1964), J. Immunol. 92, 468477.

11. Griffin, H. J. (1979), Thromb. Haemost. 42, 261 (abstr.).
XII levels are of importance for preventing the development of deep venous thrombosis (18).

This report makes it desirable to assay factor XII with a functional assay.

Taking these facts into account, determination of factor XIl can be regarded as one of the most sensitive parameters in thrombohemorrhagic diseases.

12. Colman, R. (1980), XVIIIth Congr. Haematol. Montréal, 33 (abstr).

13. Kaplan, A. P. \& Austen, K. F. (1970), J. Immunol. 105, 802-811.

14. Kaplan, A. J. \& Austen, K. F. (1971), J. Exp. Med. 133, 696-712.

15. Biggs, R. (1976), Human Blood, Coagulation, Haemostasis and Thrombosis, Blackwell Scientific. Publ. Oxford, 2 nd edit.

16. Schoenmakers, J. C. C., Matze, R., Haanen, C. \& Zilliken, F. (1965), Biochim. Biophys. Acta 93, 166-186.

17. Ratnoff, O. D., Pensky, J., Ogston, D. \& Naff, G. B. (1969), J. Exp. Med. 129, 315-331.

18. Hedner, U. (1979), Thromb. Haemost. 42, 262 (abstr.).

19. Venneröd, A. M., Laake, K., Solberg, A. K. \& Strömland, A. S. (1976), Thromb. Res. 9, 457-466.

20. Stormoken, H., Baklund, A., Gallimore, M. \& Ritland, S. (1978), Haemostasis 7, 69-76.

Dr. rer. nat. W. Dick

Zentrallabor des Lukaskrankenhauses Neuß

Preußenstraße 84

D-4040 Neuß 
